\title{
STRATEGI PENGEMBANGAN BISNIS CV. MSA DI MAJALAYA, KABUPATEN BANDUNG, JAWA BARAT
}

\author{
BUSINESS MODEL DEVELOPMENT STRATEGIC IN CV. MSA AT \\ MAJALAYA KAB . BANDUNG , JAWA BARAT
}

\author{
Muhammad Devrian Adi Putra")1, Heny K Suwarsinah"), dan Tanti Novianti ${ }^{* *}$ \\ *) Sekolah Bisnis, IPB University \\ Jl. Pajajaran Bogor 16151 \\ ${ }^{* *}$ Departemen Ilmu Ekonomi, Fakultas Ekonomi dan Manajemen, IPB University \\ Jl. Agatis Kampus IPB Darmaga, Bogor 16680
}

\begin{abstract}
Textiles industry are one of the largest non-oil and gas commodities produced for export markets segment in Indonesia, these industries create more jobs availability in Indonesia. West Java province is home for many textile industries, Majalaya, one of West Java region wellknown for its textile industry products. CV MSA factory located in Majalaya is textile company that specifically produces semi-finished woven fabrics. It is necessary for CV MSA company currently to develop new strategies to increase its capabilities related to increasing productivity and expanding its market segments. Business Model Canvas used as a basis to identify the business model. This research conducted for three months from August until October 2018 by using several internal company data, and summarized into nine business elements in business model canvas (BMC), then break it down into SWOT analysis. Data gathering conducted by observation, in-depth interviews, surveys, FGD, and literature studies. The research sample method was purposive sampling. This research used BMC to identify the business condition and finding internal \& external factors. SWOT analysis used for every business model canvas element. All elements used to design the business model canvas for the future business model. Based on elements of business in CVMSA, the managerial implications resulted in six alternative strategies.
\end{abstract}

Keywords: business model canvas, swot, textiles, woven

\begin{abstract}
Abstrak: Industri tekstil di Indonesia adalah salah satu penghasil komoditas ekspor nonmigas terbesar Indonesia, industri ini mendorong meningkatnya ketersediaan lapangan kerja di Indonesia. Jawa Barat merupakan provinsi yang memiliki banyak industri tekstil, Majalaya salah satu dari wilayah di Jawa Barat yang dikenal sebagai penghasil produk tekstil.CV MSA yang berlokasi di Majalaya merupakan perusahaan yang bergerak di bidang tekstil yang secara spesifik mengolah benang menjadi kain tenun setengah jadi. Perusahaan membutuhkan pengembangan usaha yang terkait dengan peningkatan efektifitas perusahaan dan penambahan segmen pasar. Penelitian ini ditujukan untuk mengidentifikasi model bisnis CV MSA menggunakan BMC. Penelitian ini menggunakan data yang dirangkum dalam sembilan elemen bisnis yang terdapat pada model bisnis kanvas yang selanjutnya di jabarkan pada analisis SWOT, data yang diambil dalam rentang waktu tiga bulan dari bulan Agustus hingga bulan Oktober 2018. Hasil penelitian yang dihasilkan melalui model bisnis kanvas perbaikan menunjukkan perusahaaan mampu mengembangkan segmen pasar serta melakukan diversifikasi dalam implementasi operasional yang mampu menghasilkan laba bagi perusahaan.Penelitian ini menggunakan pendekatan deskriptif. Berdasarkan hasil analisis dengan menggunakan sembilan elemen dalam bisnis model kanvas CV MSA, implikasi manajerial yang dapat dilakukan oleh manajemen terdiri dari enam macam alternatif strategi.
\end{abstract}

Kata kunci: bisnis model kanvas, swot, tekstil, tenun

\footnotetext{
${ }^{1}$ Alamat Korespondensi:

Email: devrianadi@gmail.com
} 


\section{PENDAHULUAN}

Industri tekstil merupakan salah satu industri yang mendorong pertumbuhan ekonomi di Indonesia. Selain sebagai industri yang menyumbang pendapatan negara sebagai komoditas ekspor non-migas, industri ini merupakan penyedia lapangan kerja yang cukup besar (Tambunan, 2009). Tenaga kerja yang terserap oleh industri ini baik skala menengah maupun besar pada 2012 mencapai 1,53 juta orang (Kemenperin, 2017).

Industri tekstil terdiri dari hulu, tengah dan hilir (Kuncoro, 2011). Industri tenun setengah jadi merupakan salah satu bagian dari industri tekstil di bagian tengah sebagai $b$ penenunan dari benang yang sangat penting yang menopang jalannya produksi industri garmen, memiliki karakteristik modal dan investasi sedang,menggunakan teknologi modern dan berkelanjutan, tenaga kerja yang lebih besar dibandingkan industri hulu, dan menyerap banyak tenaga listrik (API, 2011). Industri kain tenun setengah jadi memproduksi kain polos berwarna putih yang berasal dari benang bahan baku, yang diolah melalui pencelupan terlebih dahulu oleh pabrik pencelupan. Selanjutnya, hasil pencelupan akan diolah kembali oleh industri garmen atau konveksi pada skala kecil yang selanjutnya menjadi sandang yang merupakan kebutuhan pokok masyarakat seperti kantong celana, pakaian jadi,seprai, kerudung,kemeja, kain pelapis dalam tas dan kain kasur busa. Industri tenun setengah jadi sangat bergantung dengan industri pencelupan, garmen serta konveksi sebagai pembeli produk industri kain tenun setengah jadi. Data BPS 2017 menunjukkan bahwa selama periode Januari- Juni 2017, tujuan ekspor utama Indonesia adalah Amerika Serikat dengan nilai US $\$ 1,69$ miliar $(51,47 \%)$, disusul kemudian dengan Jepang dengan nilai US\$303 juta $(9,24 \%)$ dan Jerman sebesar US\$187 juta (5,71\%).

Menurut Laporan ASEAN (2018) Pasca ASEANChina Free Trade Area pada 2010 terkait eliminasi nontariff barriers antara negara-negara anggota ASEAN, menyebabkan persaingan antar industri tekstil semakin ketat, juga terjadinya serbuan produk China yang berimplikasi pada banyak pabrik tekstil melakukan relokasi pabrik ke Kabupaten Karawang dan Kabupaten Bogor, sebagai salah satu cara untuk bertahan dengan mencari upah minimum terendah yang lebih murah (Kemenperin, 2017).
Kain tenun setengah jadi adalah jenis kain putih polos yang digunakan sebagai bahan baku seprai, kantong celana, kerudung, lapisan dalam jas, lapisan dalam tas, bendera dan kemeja flannel (Kuncoro, 2013). Proses produksi kain tenun setengah jadi dimulai dari benang, gulungan benang yang terdiri dari benang biasa serta benang untuk posisi horizontal yang biasanya harus di impor, benang dimasukkan ke dalam mesin persiapan agar dapat masuk ke mesin air jetloom atau water jet loom yang selanjutnya akan merajut kain tenun setengah jadi. Setelah melakukan rangkaian produksi kain, kain harus melalui quality control agar menjamin kualitas kain yang akan dijual. Kain tenun setengah jadi ini selanjutnya dijual kepada pabrik- pabrik garmen, pabrik pencelupan UMKM maupun individu yang selanjutnya di lakukan proses pewarnaan pada kain agar dapat diolah menjadi produk- produk sandang. Kain tenun setengah jadi ini selanjutnya dijual kepada pabrikpabrik garmen, pabrik pencelupan UMKM maupun individu yang selanjutnya di lakukan proses pewarnaan pada kain agar dapat diolah menjadi produk- produk sandang (Shafaei, 2009).

Saat ini CV MSA hanya memiliki penjualan kain sebagai sumber pendapatan disatu sisi CV MSA masih harus menyisihkan pendapatannya untuk membayar kewajiban padabank sampai tahun 2019 sehingga untuk dapat membeli mesin-mesin jenis baru CV MSA mengalami kesulitan. Kesulitan lainnya adalah keterbatasan segmen pasar yang dimiliki oleh CV MSA sehingga perusahaan terlalu bergantung pada pelanggan saat ini yang memiliki kemungkinan berpindah ke produsen lain.

Perusahaan pada saat ini hanya mampu memenuhi $47 \%$ daritotalpermintaanpelanggan padamusimpuncak,yang memengaruhi pelanggan berpindah ke perusahaan lain pada musim puncak walaupun secara kualitas masih dibawah CV MSA. Perpindahan pelanggan pada musim tertentu memengaruhi permintaan produk $\mathrm{CV}$ MSA pada diluar musim puncak.Pada saat ini CV MSA masih menggunakan pemasaran secara mulut ke mulut. Menurut Tahernejad (2012), pemahaman informasi dari mulut ke mulut adalah saran yang disampaikan secara informal yang berlangsung sesama pelanggan. Dunia persaingan yang semakin ketat membuat perusahaan harus memiliki ide- ide baru dan inovasi agar dapat beradaptasi dengan perubahan lingkungan (Eppler, 2011). 
Model Bisnis merupakan suatu konsep yang menggambarkan berbagai elemen bisnis dan hubungan logis dalam menghasilkan arus pendapatan yang menguntungkan dan berkelanjutan (Supriyadi, 2006). Inovasi model bisnis sangat penting bagi perusahan dalam mencapai kesuksesan saat ini dan masa depan dengan kondisi lingkungan yang cepat berubah dan sangat kompleks menuntut para pemimpin perusahaan untuk dapat dengan cepat memahami kapan model bisnis harus beradaptasi dan bagaimana melaksanakan perubahannya (Agostini, 2014). Untuk dapat melakukan pemetaan ini maka diperlukan pengetahuan mengenai kelemahan dan kekuatan yang dimiliki oleh industri tekstil tersebut.Dengan kemampuan tersebut maka industri tekstil mampu untuk melakukan optimalisasi kesempatan serta menganalisis ancaman yang muncul terhadap industri tersebut. Menurut Liem (2009) inovasi merupakan hal yang paling penting bagi suatu institusi untuk bisa bertahan secara berkelanjutan serta menguntungkan. Inovasi berupa penemuan baru secara sistematis yang berawal dari empati, kemampuan untuk melihat dunia melalui mata orang lain, dan pemanfaatan secara optimal kemajuan teknologi yang ada. Dari tahapan proses tersebut, maka dapat disimpulkan bahwa manajemen strategik merupakan sekumpulan keputusan dan tindakan yang menghasilkan perumusan dan implementasi rencana yang didesain untuk mencapai tujuan suatu perusahaan (Balassa, 1985).

Konsep model bisnis yang sangat banyak dibicarakan salah satunya adalah business model canvas (BMC). Konsep model bisnis yang dikembangkan oleh Alexander Osterwalder dan Yves Pigneur ini berhasil mengubah konsep model bisnis yang rumit menjadi sederhana. Pada penelitian-penelitian ini yang terkait dengan komoditas tekstil yang melihat daya saing ,ekspor,serta manajemen perusahaan di industri tekstil. Susanto (2017) dengan judul Analisis Daya Saing dan Strategi Pengembangan Industri Tekstil di Indonesia dengan daya saing industi tekstil Indonesia masih cukup baik dengan nilai RCA $>1$. Namun, untuk pasar dunia yang menjadi pangsa pasar Indonesia seperti Amerika Serikat dan Eropa mengalami penurunan sedangkan untuk pasar Jepang dan Turki tren nilai RCA mengalami peningkatan. Tirta (2007) Analisis Manajemen Modal Kerja Perusahaan Industri Tekstil menunjukkan bahwa semua variable independen mempunyai hubungan dan berpengaruh positif dengan aktiva lancar dan kewajiban lancar. Asmara et al. (2014) dalam penelitiannya Struktur biaya industri dan pengaruhnya terhadap kinerja industri tekstil dan produksi tekstil Indonesia. Hengky (2000) Strategi Pemasaran Ekspor Produk Perusahaan Tekstil. Dari hasil penelitian ini ditemukan bahwa untuk dapat melakukan penetrasi pasar,dan pengembangan produk dengan cara: (1) memperkuat saluran distribusi, (2) Mengisi permintaan pasar ekspor terutama pasar negara Eropa (3) R\&D untuk menjawab permintaan kebutuhan pasar internasional (4) Memperkaya jumlah koleksi desain. Heiden (2010) yang berjudul The Review of a Business Model Canvas-Research on Changing the Business Model for a Dutch Tour Operatoryaitu business model canvas, analisis SWOT, critical success factor dan memberikan rekomendasi untuk meningkatkan model bisnis saat ini. Baso dan Astuti (2013) dengan hasil 1) 7 opportunities dan 5 threats dengan total nilai EFE Matrix 2,79, dimana bisnis tekstil di Cigondewah mampu menanggapi kesempatan dan ancaman dengan cukup baik. Sianipar (1998). Dalam penelitian Kajian Sistem Pengendalian Mutu Produk Garment pada PT. Busana Perkasa Garments Bogor menggunakan Analisis Pareto, Diagram SebabAkibat, Control Chart. Maryani (2000) yaitu Kajian Pengendalian Mutu Proses Produksi Garmen Di PT. Citra Abadi Sejati, menggunakan analisis diagram Parreto dan sebab-akibat. Purwadi (2012) Pengaruh Faktor Internal dan Eksternall terhadap Profitabilitas Perusahaan Tekstil yang Terdaftar di Bursa Efek Indonesia tahun 2005-2011.Profitabilitas merupakan faktor yng sangat penting agar perusahaan dapat berkembang.Profitabilitas perusahaan dipengaruhi oleh faktor internal \& ekternal.

Sementara pada penelitian-penelitian berikut, terkait dengan metode dalam menganalisis strategi yang telah dilakukan oleh perusahaan, Nurmanisa et al. (2016) Melakukan penelitian Analisis customer segment,Channels dan customer relationship dalam pembentukan value proposition Starbucks Coffee. Marahakim dan Wandebori(2012) melakukan penelitian Business Model Generation of Majalah EPIK yang telah dipublikasikan di Journal of Business Management. Penelitian ini menerangkat model bisnis pada majalah yang menargetkan segmen pasar pembaca muda. Hidayat (2002) Menggunakan analisis internal dan eksternal untuk kemudian dipetakan kedalam matriks IE selanjutnya menggunakan matriks SWOT, sehingga akan diperoleh beberapa alternative strategiyang dapat diplotkan terhadap matriks IE. Lingga (2001) dengna judul Formulasi Strategi Bisnis PT. Sierad Feedmil. Penelitian ini bertujuan untuk mengidentifikasikan faktor-faktor yang menjadi kekuatan, kelemahan, 
peluang dan ancaman PT. Sierad Feedmil. Prambudyo (2002) melakukan penelitian dengan judul Formulasi Strategi CV Enggal Pratama dalam Menghadapi Perubahan Lingkungan yang berlokasi di Kecamatan Majalaya Kabupaten Bandung CV Enggal Pratama sebuah perusahaan yang bergerak di bidang tekstil tradisional terutama sarung tenun.

Tujuan dilakukannya penelitian ini adalah menganalisis model bisnis yang telah diterapkan oleh CV MSA berdasarkan Sembilan elemen Model Bisnis Kanvas. Selanjutnya, melakukan identifikasi kekuatan, kelemahan, peluang, dan ancaman yang ada di CV MSA. Di samping itu, merumuskan model bisnis kanvas barusebagai upaya perbaikan untuk mendukung pengembangan bisnis di CV MSA serta merumuskan strategi pengembangan bisnis CV MSA di masa depan.

\section{METODE PENELITIAN}

Penelitian dilaksanakan selama tiga bulan dari Agustus hingga Oktober 2018 di CV MSA Kabupaten Bandung, Jawab Barat. Pemilihan lokasi dilakukan secara sengaja (purposive) dengan pertimbangan $\mathrm{CV}$ MSA memiliki potensi untuk dapat dikembangkan. Penelitian ini menggunakan dua jenis data yaitu primer dan sekunder yang diperoleh dari perusahaan maupun eksternal. Pengumpulan data digunakan dengan tujuan untuk memperoleh data dan informasi yang diperlukan untuk menjawab pertanyaan dalam rumusan masalah penelitian. Dokumen bisa berbentuk tulisan, gambar, atau karya-karya monumental dari seseorang. Wawancara dilakukan bersama key informant antara lain Direktur,Wakil Direktur dan melaui FGD dengan internal perusahaan, sedangkan dokumentasi data berupa foto kegiatan dan profil.

Metode yang digunakan dalam penelitian ini adalah metode deskriptif untuk memperoleh gambaran informasi, penjelasan, dan kondisi yang berkaitan dengan objek penelitian secara akurat dan sistematis. Penelitian dengan metode studi kasus menghendaki suatu kajian yang rinci, mendalam dan menyeluruh (Umar, 2002).

Studi ini menggunakan pendekatan BMC sebagai platform untuk melakukan pemetaan Business Model perusahaan saat ini. Pendekatan BMC tersebut berpedoman pada kuesioner yang digunakan pada saat
FGD serta In Depth Interview yang diberikan kepada para responden. Pertanyaan kuesioner mengacu pada Sembilan elemen yang terdapat dalam BMC sehingga dapat melihat gambaran Model Bisnis perusahaan saat ini secara akurat. Di samping itu, direct observation terhadap hal- hal yang tidak tercakup dalam kuesioner juga dilakukan untuk menghasilkan suatu alternatif strategi yang sesuai dengan kondisi yang terdapat dilapangan. Setelah pengisian kuesioner dengan wawancara kepada key person dilanjutkan dengan analisis dengan menggunakan SWOT untuk setiap elemen dari BMC sebagai bahan untuk penyempurnaan, yang pada akhirnyadibuat strategi pengembangan.

Teknik penentuan responden yang digunakan pada penelitian ini adalah non probability sampling dengan teknik purposive sampling (dilakukan secara sengaja), dengan menggunakan teknik purposive maka penulis secara langsung dapat memilih sendiri pihak-pihak yang menjadi syarat responden yang secara pasti mengetahui kondisi CV MSA. Responden yang dibutuhkan dalam penelitian terdiri dari kalangan internal perusahaan CV MSA yang memiliki pengetahuan mengenai perusahaan, memiliki kewenangan dalam perumusan dan pelaksanaan strategi.

Wawancaradilakukankepadapihak-pihakyangmemiliki kewenangan dalam membuat kebijakan di perusahaan CV MSA, yaitu pemilik beserta jajaran pegawai melalui proses FGD. Wawancara melalui bantuan pertanyaan dilaksanakan secara mendalam kepada direktur CV MSA dan komanditer atau wakil direktur. Pendekatan kualitatif yang digunakan berdasarkan data/informasi deskriptif berupa kata- kata tertulis atau lisan dari narasumber serta perilaku yang dapat diamati terkait subjek yang diteliti sehingga menemukan fakta. Proses FGD dilakukan selama empat kali dimulai pada saat pemetaan sembilan elemen dari Model Bisnis Kanvas,selanjutnya dilakukan evaluasi model bisnis dan melakukan SWOT pada masing-masing elemen, FGD dilakukan kembali dalam membangun Model Bisnis Masa Depan dan dalam menentukan alternatif pengembangan strategi.Model Bisnis merupakan suatu konsep yang menggambarkan berbagai elemen bisnis dan hubungan logis dalam menghasilkan arus pendapatan yang menguntungkan dan berkelanjutan (Supriyadi, 2006). Menurut Osterwalder (2010), BMC adalah sebuah model bisnis gambaran logis mengenai bagaimana sebuah perusahaan menciptakan, menghantarkan dan menangkap sebuah nilai model bisnis dapat melayani tiga tujuan berbeda. 
Teknik pengolahan dan analisis data yang dilakukan dalam penelitian ini, adalah analisis deskriptif untuk mendapatkan gambaran umum secara menyeluruh; mendesain model bisnis (BMC), dengan mengikuti tiga langkah (tim PPM Manajemen, 2012):

1) Potret atau petakan model bisnis saat ini yang sebenarnya terjadi. Dalam tahap awal dari mendesain model bisnis, dimulai dari mengidentifikasikan customer segments. Hal ini dilakukan karena hanya pelanggan yang memberikan profit margin bagi perusahaan yang akan menghidupi perusahaan. Setelah customer segments didefinisikan merupakan pernyataan keunikan produk atau jasa yang dijanjikan perusahaan kepada customer segments yang dibikan. Namun, bisa saja terjadi value propositions memengaruhi customer segments yang akan dipilih. Perusahaan perlu melakukan edukasi bagi customer segments yang dibidik, agar bersedia menerima value propositions yang ditawarkan oleh perusahaan. Channels mengkomunikasikan, mengantar, dan berinteraksi dengan pelanggannya. Perlu diperhatikan bahwa kesuksesan dalam kegiatan Channels sangat ditentukan oleh efektifitas dari key resources, key activities, dan key partners. Customers relationship adalah seberapa besar kegiatan perusahaan menjaga hubungan dengan pelanggan lama seberapa giat perusahaan dalam menjaring pelanggan baru atau meningkatkan penjualan produk/ jasa ke pelanggan lama. Apabila customer segments dapat difokuskan atau dipersempit dengan baik, value propositions dinyatakan secara tajam serta Channels dan customer relationship dijaga secara baik dan benar, maka revenue streams akan berhasil memberikan pendapatan kedalam perusahaan. Kegiatan seperti key resources, key activities, dan key partners harus dimanajemen secara baik dan efisien. Efisiensi dalam pengelolaan tiga elemen terakhir sangat diperlukan untuk menjaga cost structure tetap optimal. Hal yang perlu disadari adalah dalam mendesain model bisnis yaitu menjaga keterkaitan antar elemen, karena perubahan pada satu elemen akan berdampak pada elemen lainnya.

2) Lakukan analisis SWOT pada masing-masing elemen dari Sembilan elemen model bisnis. Sebagai contoh pada elemen customer segments, kemampuan memilih customer segment yang memiliki populasi besar dan dapat menguntungkan dapat diklasifikasikan sebagai kekuatan, pasar potensial dan belum tergarap sebagai peluang, dan munculnya pesaing sejenis dapat dikategorikan sebagai ancaman.

3) Lakukan penyempurnaan model bisnis dan/ atau membuat purwarupa. Dari hasil analisis SWOT kemudian dapat digunakan menjadi dua tujuan. Tujuan yang pertama untuk menyempurnakan model bisnis yang ada saat ini, dan tujuan yang kedua melahirkan purwarupa model bisnis yang baru maka dapat saja perusahaan tersebut memilih menggunakan model bisnis yang disempurnakan. ketiga, model bisnis yang telah melalui penyempurnaan dapat diaplikasikan pada strategi pengembangan dan pembuatan program yang sesuai di CV MSA.

Dapat dilihat pada Gambar 1 setelah memetakan model bisnis CV. MSA analisis lingkungan model bisnis digunakan untuk melihat dan menganalisis lingkungan eksternal atau lingkungan perusahaan. Setelah menganalisis ketiga komponen tersebut, selanjutnya dilakukan evaluasi model bisnis di CV. MSA dengan cara melakukan breakdown dari sembilan elemen bisnis kepada SWOT.Setelah mengetahui kekuatan, kelemahan, peluang, dan ancaman yang ada, kemudian dilakukan penetapan desain pengembangan model bisnis masa depan menggunakan BMC, yang kemudian dilakukan penetapan dan pemilihan alternatif pengembangan strategi yang selanjutnya penentuan strategi bisnis CV MSA di masa depan.

\section{HASIL}

\section{Pemetaan Sembilan Elemen Model BisnisCV. MSA Saat Ini}

Tahapan awal yang dilakukan untuk menyusun strategi pengembangan pada bisnis, yaitu dengan melakukan identifikasi model bisnis saat ini berdasarkan sembilan elemen bisnis model kanvas. Berdasarkan hasil wawancara dan FGD dengan responden pihak internal, didapatkan gambaran kesembilan elemen model bisnis CV MSA. Dengan mengidentifikasi dan mengevaluasi masing-masing elemen, maka akan didapatkan bagian dari elemen mana yang kurang tepat dan belum maksimal, sehingga dapat dirancang strategi pengembangan model bisnis CV MSA masa depan. Pemetaan sembilan elemen model bisnis perusahaan CV MSA saat ini berdasarkan hasil wawancara pihak internal dan observasi langsung dapat dilihat pada Gambar 2. 
Setelah mengidentifikasi sembilan elemen bisnis model kanvas CV MSA, maka langkah selanjutnya yaitu melakukan analisis SWOT pada setiap elemen bisnis kanvas CV MSA. Menurut Nikolao dan Evangelinos (2010) analisis SWOT dapat menjadi alat yang berguna untuk perencanaan strategis proses pengelolaan lingkungan.Analisis SWOT didasarkan pada logika yang dapat memaksimalkan kekuatan dan peluang (Slavik dan Berdnar, 2014). Pada penelitian ini, ditentukan prioritas SWOT melalui FGD dengan pihak internalCV MSA. Hasil prioritas SWOT pada setiap elemen bisnis kanvas CV MSA pada Tabel 1.

\section{Perbaikan Model Bisnis Kanvas CV.MSA}

Setelah melakukan pemetaan sembilan elemen bisnis kanvas CV MSA dan menetapkan hasil analisis SWOT pada setiap elemennya maka diperoleh perbaikan model bisnis yang baru. Dalam perbaikan model bisnis ini dibagi dalam jangka pendek dan jangka panjang dengan skala prioritas, sesuai dengan hasil FGD dan In depth interview yang dilaksanakan bersama pihak internal CV MSA. Gambar 3 menyajikan perbaikan model bisnis kanvas CV. MSA.

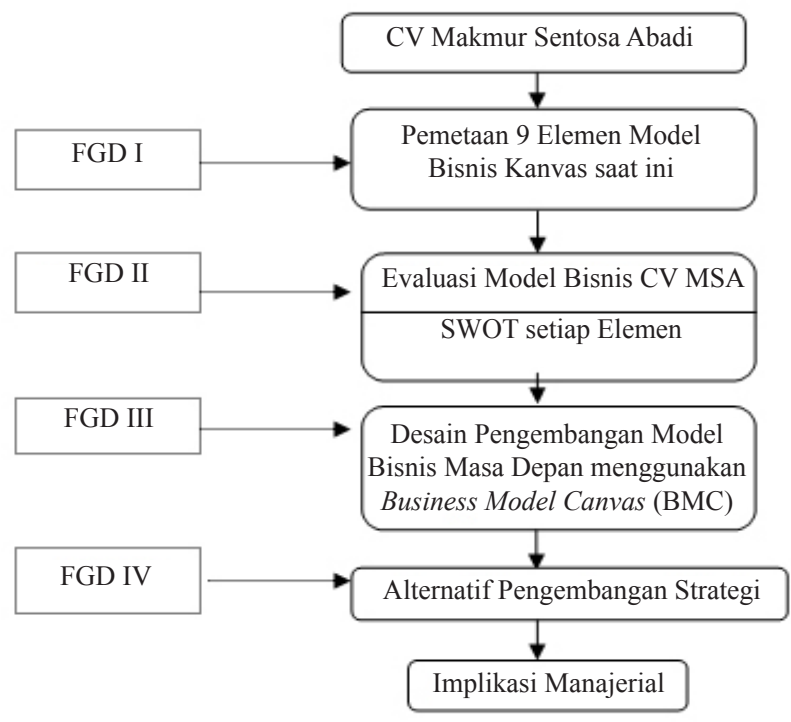

Gambar 1. Kerangka pemikiran penelitian

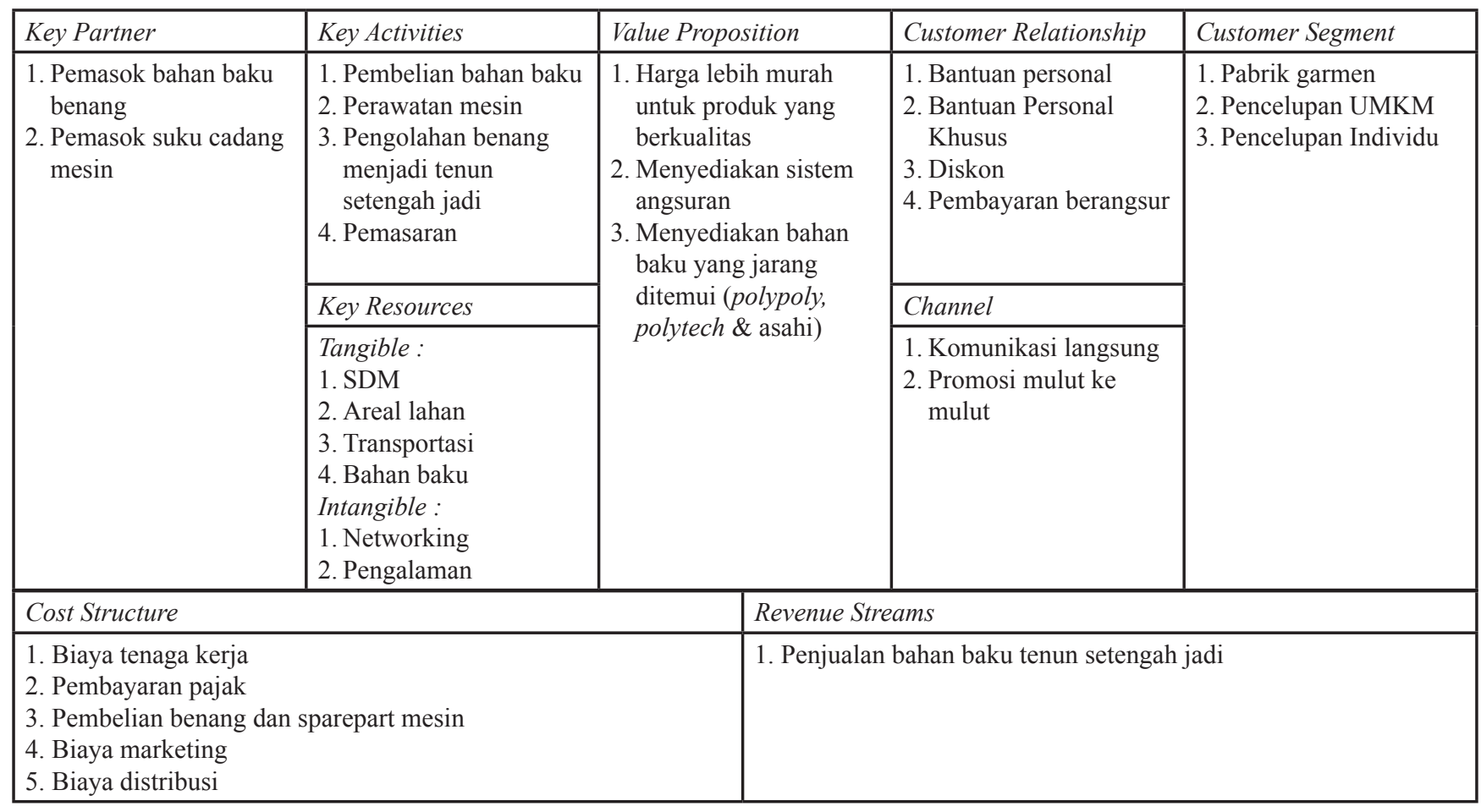

Gambar 2. Pemetaan sembilan elemen model bisnis CV MSA saat ini 
Tabel 1. Analisis SWOT pada sembilan elemen bisnis kanvas di CV MSA

\begin{tabular}{|c|c|c|c|c|}
\hline Elemen & Kekuatan & Kelemahan & Peluang & Ancaman \\
\hline Customer Segment & $\begin{array}{l}\text { - Menyediakan banyak } \\
\text { ragam produk seperti } \\
\text { Polypoly, Polytech, } \\
\text { Asahi }\end{array}$ & $\begin{array}{l}\text { - Perusahaan tidak } \\
\text { memiliki segmen pasar } \\
\text { yang luas }\end{array}$ & $\begin{array}{l}\text { - Munculnya toko - } \\
\text { toko daring. } \\
\text { - Individu yang } \\
\text { memiliki usaha } \\
\text { pewarnaan kain } \\
\text { - Supplier bahan baku } \\
\text { murah } \\
\text { - Pemesanan secara } \\
\text { Daring }\end{array}$ & $\begin{array}{l}\text { - } \text { Tingkat berpindah } \\
\text { pelanggan tinggi } \\
\text { - Banyaknya pabrik sejenis } \\
\text { yang menawarkan harga } \\
\text { murah untuk kualitas } \\
\text { dibawah } \\
\text { Standard } \\
\text { - Kurangnya kesadaran } \\
\text { konsumen terhadap } \\
\text { kualitas kain. }\end{array}$ \\
\hline Value Proposition & $\begin{array}{l}\text { - Kain tenun setengah } \\
\text { jadi yang berkualitas } \\
\text { grade A } \\
\text { - Harga lebih murah } \\
\text { dibandingkan } \\
\text { kompetitor sejenis } \\
\text { - Memiliki jenis kain } \\
\text { yang jarang ditemui }\end{array}$ & $\begin{array}{l}\text { - Ketersediaan kain tidak } \\
\text { mencukupi dengan } \\
\text { permintaan konsumen } \\
\text { pada musim-musim } \\
\text { tertentu }\end{array}$ & $\begin{array}{l}\text { - Meningkatnya } \\
\text { kebutuhan atas kain } \\
\text { tenun setengah jadi }\end{array}$ & $\begin{array}{l}\text { Kurangnya Dukungan } \\
\text { dari pemerintah daerah } \\
\text { - Konsumen individu } \\
\text { cenderung memilih } \\
\text { produk Grade B yang } \\
\text { lebih murah }\end{array}$ \\
\hline Channel & $\begin{array}{l}\text { - Pengantaran sesuai } \\
\text { perjanjian }\end{array}$ & $\begin{array}{l}\text { - Promosi kurang } \\
\text { - } \text { Kerusakan produk } \\
\text { saatdidistribusikan }\end{array}$ & $\begin{array}{l}\text { - Permintaan kain dari } \\
\text { daerah lain } \\
\text { - Promosi event- } \\
\text { event produk tekstil } \\
\text { Indonesia }\end{array}$ & $\begin{array}{l}\text { - Pengambil alihan saluran } \\
\text { oleh pesaing }\end{array}$ \\
\hline $\begin{array}{l}\text { Customer } \\
\text { Relationship }\end{array}$ & $\begin{array}{l}\text { - after sales seperti } \\
\text { penggantian produk } \\
\text { yang rusak } \\
\text { - Menerapkan sistem } \\
\text { pembayaran berangsur } \\
\text { - Diskon untuk jumlah } \\
\text { pembelian tertentu }\end{array}$ & $\begin{array}{l}\text { - Hubungan pelanggan } \\
\text { lemah } \\
\text { - Biaya berpindah } \\
\text { pelanggan baru tinggi } \\
\text { - Kurang dikenalnya nama } \\
\text { perusahaan }\end{array}$ & $\begin{array}{l}\text { - Penggunaan sistem } \\
\text { daring }\end{array}$ & $\begin{array}{l}\text { - Daya tawar yang dimiliki } \\
\text { oleh konsumen }\end{array}$ \\
\hline Revenue Streams & $\begin{array}{l}\text { - Pendapatan dari } \\
\text { kontrak kerjasama } \\
\text { dengan beberapa } \\
\text { perusahaan }\end{array}$ & $\begin{array}{l}\text { - Sumber pendapatan } \\
\text { hanya } 1 \text { yaitu penjualan } \\
\text { - Konsumen tidak } \\
\text { melakukan pembayaran } \\
\text { tepat waktu } \\
\text { - Perusahaan harus } \\
\text { mengeluarkan biaya } \\
\text { tinggi sebelum menerima } \\
\text { pembayaran }\end{array}$ & $\begin{array}{l}\text { - Penyewaan alat-alat } \\
\text { produksi } \\
\text { - Penjualan bahan } \\
\text { baku }\end{array}$ & $\begin{array}{l}\text { - Pembayaran tidak } \\
\text { dilakukan oleh konsumen }\end{array}$ \\
\hline Key Resources & $\begin{array}{l}\text { - Tenaga kerja produksi } \\
\text { berpengalaman } \\
\text { - Memiliki alat produksi } \\
\text { yang modern }\end{array}$ & $\begin{array}{l}\text { - Sumberdaya utama } \\
\text { mudah ditiru } \\
\text { - transportasi yang } \\
\text { dimiliki } \\
\text { - Tenaga kerja yang } \\
\text { dimiliki kurang } \\
\text { - Kurangnya modal untuk } \\
\text { pembelian alat-alat } \\
\text { produksi } \\
\text { - Ketersediaan bahan } \\
\text { baku tidak sesuai dengan } \\
\text { permintaan konsumen } \\
\text { skala besar }\end{array}$ & $\begin{array}{l}\text { - } \text { Kerjasama dengan } \\
\text { perusahaan } \\
\text { transportasi } \\
\text { pengangkutan barang }\end{array}$ & $\begin{array}{l}\text { - Pasokan bahan baku } \\
\text { impor yang sulit dicari }\end{array}$ \\
\hline Key Activities & $\begin{array}{l}\text { - Pengolahan bahan baku } \\
\text { dengan efisien }\end{array}$ & $\begin{array}{l}\text { - Sumberdaya utama } \\
\text { mudah ditiru } \\
\text { - Kemampuan produksi } \\
\text { tidak maksimal pada } \\
\text { musim-musim tertentu }\end{array}$ & $\begin{array}{l}\text { - Penggunaan } \\
\text { teknologi terbaru } \\
\text { - Menyewakan mesin } \\
\text { produksi }\end{array}$ & $\begin{array}{l}\text { - Harga Bahan baku yang } \\
\text { naik turun } \\
\text { - Regulasi pemda yang } \\
\text { memengaruhi pemesanan }\end{array}$ \\
\hline
\end{tabular}


Tabel 1. Analisis SWOT pada sembilan elemen bisnis kanvas di CV MSA (Lanjutan)

\begin{tabular}{|c|c|c|c|c|}
\hline Elemen & Kekuatan & Kelemahan & Peluang & Ancaman \\
\hline Key Partner & $\begin{array}{l}\text { - Bekerjasama dengan } \\
\text { kompetitor sejenis }\end{array}$ & $\begin{array}{l}\text { - Ketidaktersediaan } \\
\text { bahan baku benang } \\
\text { - Sulitnya perusahaan } \\
\text { mendapatkan mitra } \\
\text { dari luar negeri } \\
\text { - Sangat bergantung } \\
\text { pada mitra }\end{array}$ & $\begin{array}{l}\text { - Penyewa mesin } \\
\text { produksi } \\
\text { - Kerjasama dengan } \\
\text { perusahaan logistic }\end{array}$ & $\begin{array}{l}\text { - Adanya kolaborasi } \\
\text { mitra dengan pesaing } \\
\text { (kompetitor) }\end{array}$ \\
\hline Cost Structure & $\begin{array}{l}\text { - Perusahaan } \\
\text { mendapatkan } \\
\text { keuntungan dari } \\
\text { economic of scope } \\
\text { - Beban yang dimiliki } \\
\text { kecil }\end{array}$ & $\begin{array}{l}\text { - Pencatatan akuntansi } \\
\text { belum tersistematis } \\
\text { masih menggunakan } \\
\text { excel }\end{array}$ & $\begin{array}{l}\text { - Pembiayaan } \\
\text { melalui institusi } \\
\text { keuangan non-bank } \\
\text { atau menambah } \\
\text { investor untuk } \\
\text { pembelian mesin - } \\
\text { mesin }\end{array}$ & $\begin{array}{l}\text { - Terjadinya kenaikan } \\
\text { harga BBM } \\
\text { - Harga Bahan baku } \\
\text { tidak stabil } \\
\text { - } \text { Masih menjadi debitur } \\
\text { perbankan hingga } \\
2019\end{array}$ \\
\hline
\end{tabular}

\begin{tabular}{|c|c|c|c|c|c|}
\hline Key Partner & Key Activities & \multicolumn{2}{|c|}{ Value Proposition } & Customer Relationship & Customer Segment \\
\hline \multirow{3}{*}{$\begin{array}{l}\text { 1. Pemasok bahan baku } \\
\text { benang } \\
\text { 2. Pemasok suku cadang } \\
\text { mesin } \\
\text { 3. Penambahan } \\
\text { Pemasok Benang } \\
\text { baru dan suku } \\
\text { cadang* } \\
\text { 4.Perusahaan logistik** } \\
\text { 5.Perusahaan } \\
\text { kompetitor sejenis* }\end{array}$} & $\begin{array}{l}\text { 1. Pembelian bahan baku } \\
\text { 2. Perawatan mesin } \\
\text { 3. Pengolahan benang } \\
\text { menjadi tenun } \\
\text { setengah jadi } \\
\text { 4. Pemasaran } \\
\text { 5. Penyewaan mesin * }\end{array}$ & \multirow{3}{*}{\multicolumn{2}{|c|}{$\begin{array}{l}\text { 1. Harga lebih murah } \\
\text { untuk produk yang } \\
\text { berkualitas } \\
\text { 2. Menyediakan sistem } \\
\text { angsuran } \\
\text { 3. Menyediakan } \\
\text { bahan baku yang } \\
\text { jarang ditemui } \\
\text { (polypoly,polytech\& } \\
\text { asahi) } \\
\text { 4. Menyediakan } \\
\text { penyewaan mesin } \\
\text { serta menjual bahan } \\
\text { baku benang* }\end{array}$}} & $\begin{array}{l}\text { 1. Bantuan personal } \\
\text { 2. Bantuan Personal } \\
\text { Khusus } \\
\text { 3. Diskon } \\
\text { 4. Pembayaran berangsur } \\
\text { 5.Menggunakan } \\
\text { platform daring* }\end{array}$ & \multirow[t]{3}{*}{$\begin{array}{l}\text { 1. Pabrik garmen } \\
\text { 2. Pencelupan UMKM } \\
\text { 3. Pencelupan Individu } \\
\text { 4. Penyewa mesin } \\
\text { produksi* }\end{array}$} \\
\hline & Key Resources & & & Channel & \\
\hline & $\begin{array}{l}\text { Tangible : } \\
\text { 1. SDM } \\
\text { 2. Areal lahan } \\
\text { 3. Transportasi } \\
\text { 4. Bahan baku } \\
\text { 5. Penambahan tenaga } \\
\text { kerja ** } \\
\text { 6. Pemanfaatan } \\
\text { teknologi Water jet } \\
\text { loom** } \\
\text { Intangible: } \\
\text { 1. Networking } \\
\text { 2. Pengalaman } \\
\end{array}$ & & & $\begin{array}{l}\text { 1. Komunikasi langsung } \\
\text { 2. Promosi mulut ke } \\
\text { mulut } \\
\text { 3.Media Internet* } \\
\text { 4.Aktif dalam event } \\
\text { pameran** }\end{array}$ & \\
\hline \multicolumn{3}{|l|}{ Cost Structure } & \multicolumn{3}{|c|}{ Revenue Streams } \\
\hline \multicolumn{3}{|c|}{$\begin{array}{l}\text { 1. Biaya tenaga kerja } \\
\text { 2. Pembayaran pajak } \\
\text { 3. Pembelian benang dan sparepart mesin } \\
\text { 4. Biaya marketing } \\
\text { 5. Biaya distribusi } \\
\text { 6.Penambahan biaya tenaga kerja ** } \\
\text { 7.Penambahan biaya membuat aplikasi untuk sistem internal** } \\
\text { 8.Penambahan biaya promosi ** } \\
\text { 9.Penambahan biaya distribusi** }\end{array}$} & \multicolumn{3}{|c|}{$\begin{array}{l}\text { 1. Penjualan bahan baku tenun setengah jadi } \\
\text { 2. Penyewaan alat - alat produksi* } \\
\text { 3. Penjualan bahan baku benang* }\end{array}$} \\
\hline
\end{tabular}

Gambar 3. Perbaikan Model bisnis kanvas CV MSA $\left({ }^{*}\right)$ penambahan komponen jangka pendek; ${ }^{* *}$ penambahan komponen jangka panjang) 
Hasil dari perbaikan bisnis model kanvas muncul faktor penambahan atau penciptaan atau keduanya dari masing-masing sembilan elemen bisnis model kanvas. Faktor penambahan dibutuhkan agar meningkatkan penjualan dan produksi agar CV MSA mampu memenuhi target keuntungan yang diinginkan.Faktor penciptaan dibutuhkan agar perusahaan mampu menawarkan hal-hal yang belum ada sebelumnya belum ditawarkan oleh perusahaan lain.

\section{Alternatif Strategi Pengembangan Bisnis CV MSA}

Pengembangan dan perbaikan model bisnis CV MSA yang telah dilakukan melalui hasil analisis SWOT pada sembilan elemen bisnis kanvas, selanjutnya dapat digunakan sebagai penentuan alternatif pengembangan strategi bisnis untuk mendukung program perbaikan bisnis. Menurut Adelita et al. (2010) menyatakan bahwa, penentuan harga ditentukan oleh tren yang berkembang, yaitu semakin bersifat massal maka harga akan semakin turun. Jika diamati produk - produk tekstil selalu menjadi kebutuhan masyarakat terlepas tren apapun yang sedang berlangsung, karena industri tekstil dapat menyesuaikan dengan tren pasar.Beberapa alternatif strategi yang diperoleh dengan melakukan metode FGD bersama pihak internal perusahaan yang memungkinkan terbagi dalam jangka pendek dan jangka panjang untuk dijalankan, didapatkan sebagai berikut:Pengembangan Segmen Pasar

Pada jangka pendek CV MSA dapat melakukan penyewaan mesin dan penjualan bahan baku benang. Penyewaan dapat dilakukan pada musim biasa, saat posisi mesin tidak banyak terpakai. Penyewa mesin dapat membawa sendiri bahan baku benang atau dapat membeli benang dari CV MSA sesuai dengan kebutuhan yang diinginkan oleh penyewa. Penyewa selanjutnya tinggal membayarkan biaya pembuatan serta tenaga kerja, hal ini perlu dilakukan karena pasar ini memiliki potensi pembeli namun tidak memiliki kecukupan modal untuk membangun pabrik, serta menambah arus pendapatan perusahaan tanpa harus mengganggu penjualan produk dari CV MSA itu sendiri.

Dalam jangka panjang keikutsertaan CV MSA pada pameran, expo, bazaar dan seminar,akan membuka peluang terhadap pengembangan pasar. Strategi ini didasari oleh adanya penambahan padacustomer segment baru. Menurut Kosasi (2015), cara paling efektif dalam berkomunikasi dengan pelanggan adalah melalui pelayanan secara langsung dengan hospitality yang telah diajarkan, karena salah satu faktor yang memengaruhi konsumen untuk kembali atau tidak adalah dengan pelayanan yang ditawarkan, selain kualitas produk.Menurut Berman (2012), keputusan pelanggan dalam memilih suatu produk semakin banyak dipengaruhi oleh informasi yang diperoleh dari jejaring sosial atau media daring.

Munculnya penambahan pada saluran pelanggan yang baru yaitu event atau pameran dapat menjadikan value proposition yang belum sempat perusahaan jalankan. Peningkatan Kuantitas Produk ,strategi ini digunakan untuk jangka panjang setelah perusahaan mampu melakukan penambahan mesin. Strategi peningkatan kuantitas produk memiliki beberapa landasan awal yaitu pada kekurangan perusahaan seperti kemampuan produksi yang belum mencukupi dengan permintaan konsumen skala besar, produk yang kalah bersaing dengan produk pesaing dengan kualitas dibawah, belum memaksimalkan kegiatan promosi.Menjadikan strategi ini menjadi salah satu strategi yang diperhatikan oleh CV MSA .Peningkatan kuantitas produk berhubungan dengan inovasi yang dihasilkan oleh CV MSA sendiri. Inovasi yang dapat dilakukan CV MSA adalah dengan menggunakan sistem teknologi water jet loom untuk menciptakan produk yang berkualitas, memaksimalkan produksi. Penambahan tenaga kerja pada bidang produksi didasari oleh adanya penambahan komponen pada customer segment, sehingga value proposition pada bidang sistem sewa, penjualan kain tenun setengah jadi dan bahan baku benang, yang akan berakibat pada aktivitas kunci yaitu produksi dan perawatan mesin seperti penggantian suku cadang pun akan bertambah. Kurangnya tenaga kerja produksi akan menghambat produksi kain.Selanjutnya dibutuhkannya staf yang memahami pemasaran di internet. Sehingga, penambahan tenaga kerja dinilai tepat untuk keberlangsungan perusahaan.

Pemanfaatan teknologi dan inovasi merupakan salah satu strategi yang didalamnya terdapat pemasaran serta transaksi secara daring dan penambahan penggunaan mesin water jet loom. Menurut (Dawson dan Moseley, 1974) Water jet looms memiliki efisiensi secara konsumsi energi dan tidak menimbulkan polusi suara. Pada jangka pendek CV MSA dapat menggunakan internet sebagai alat pemasaran . Penggunaan internet digunakansebagaicara untukmelakukanpemasaranbaik via situs daring maupun media sosial, Perusahaan dapat melakukan transaksi melalui perbankan konvensional \& non-konvensional secara daring.Untuk perjanjian 
kerja sama dan transaksi pun dapat menggunakan platform yang baru secara daring. Selanjutnya, potensi lain pada jangka panjang adalah penggantian mesin water jet loom secara menyeluruh akan menambah efisiensi penggunaan material pembuatan kain serta menambah kemampuan produksi dibandingkan jenis mesin sebelumnya air jet loom.Penambahan mitra penyedia bahan baku dan suku cadang sesuai dengan permintaan konsumen. Kerjasama dengan mitra media bahan baku benang dan suku cadang dilakukan untuk menghindari ancaman terhadapat harga bahan baku yang tidak stabil dan menghindari pasokan bahan baku inti yang sulit di dapat.Penambahan mitra lain yaitu jasa logistik dimaksudkan untuk menambah pasokan distribusi ke berbagai kelompok pelanggan potensial.

Penambahan mitra kompetitor sejenis merupakan salah satu strategi baru yang ingin dikembangkan oleh CV MSA.Perusahaan mengakui bahwa kekurangan $\mathrm{CV}$ MSAadalah belum dapat memaksimalkan kegiatan operasional sesuai dengan kebutuhan konsumen. Maka dari itu perusahaan harus dapat memenuhi kebutuhan konsumen,salah satu caranya adalah dengan menjual kembali kain tenun setengah jadi dari kompetitor sejenis yang sesuai dengan keinginan konsumen. Hal ini dilakukan pada saat momen-momen dimana permintaan akan kain sedang tinggi namun perusahaan tidak dapat menyediakan.Perusahaan dapat mencari kain dari kompetitor sejenis sesuai kualitas yang diinginkan oleh konsumen.Melalui cara ini perusahaan masih mendapatkan margin keuntungan dibandingkan konsumen membeli langsung ke kompetitor. Penambahan Modal Usaha, Apabila dilihat dari BMC yang baru, CV MSA menambah elemen cost structure berupa penambahan gaji karyawan, pembelian bahan baku, biaya promosi, dan distribusi. CV MSA menambahkan komponen pada value proposition yaitu menyediakan penyewaan mesin, hal tersebut dapat berpengaruh kepada key resources karena pembuatan kain tenun setengah jadi membutuhkan tenaga kerja yang tidak sedikit, transportasi, dan juga mesin produksi yang lebih banyak. Oleh sebab itu, hal tersebut berpengaruh kepada biaya yang dikeluarkan oleh perusahaan.

\section{Implikasi Manajerial}

Hasil penelitian ini merupakan perbaikan model bisnis yang berimplikasi pada rekomendasi kebijakan yang dapat dilakukan oleh CV MSA.Terdapat 2 tahapan pengembangan model bisnis secara jangka pendek dan jangka panjang.Implementasi strategi jangka pendek dapat dilakukan dalam rentang waktu 6-8 bulan. Salah satu cara yaitu penyewaan mesin dan penjualan bahan baku benang dibeberapa daerah yang dianggap tepatoleh perusahaan. Penerapan strategi ini diharapkan mampu menopang rencana jangka panjang yang diinginkan oleh CV MSA.Penambahan mitra potensial seperti mitra pemasok benang, pemasok suku cadang, perusahaan logistik, dan perusahaan kompetitor. Penambahan tenaga kerja dan peningkatan sumber daya manusia juga berguna kepada masyarakat banyak, seperti salah satu misi CV MSA yaitu membuka pekerjaan bagi masyarakat.CV MSA juga dapat menggunakan internet untuk menjaring segmen pasar yang lebih luas tidak terbatas di Majalaya.

Sementara dalam jangka panjang implementasi strategi dapat dilakukan setelah pelunasan hutang pada perbankan lalu adanya penambahan modal dari investor. CV MSA dapat melakukan pemanfaatan teknologi dan inovasi.Penambahanmesinwater jet loom dilakukan untuk meningkatkan kualitas produk kain tenun setengah jadi. Perusahaan dapat menambah investor atau meminjam ke lembaga keuangan untuk dapat menambah mesin - mesin pemintalan jenis baru setelah perusahaan mampu melakukan pelunasan pada bank pada tahun 2019. Alur dan konfigurasi untuk menjahit benang bahan baku menjadi kain tenun pada water jet loom telah melalui proses analisis yang panjang (Yan, 2014). Ikut serta dalam berbagai pameran-pameran atau expo, bazar, terkait tekstil seperti Indointertex, Intex show, dan Textech Indonesia untuk dapat membantu mencari dan mendapatkan segmen pelanggan baru. Beberapa cara tersebut dapat dilakukan oleh CV MSA untuk mengembangkan pasar kain tenun setengah jadi.

\section{KESIMPULAN DAN SARAN}

\section{Kesimpulan}

Berdasarkan pemetaan sembilan elemen model bisnis kanvas dapat ditemukan bahwa diperlukan perbaikan dalam model bisnis yang sudah dijalankan oleh CV MSA yang mencakup beberapa elemen, yaitu customer segments yang terbatas, customer relationship masih menggunakan metode yang tradisional, channelsyang masih bersifat tradisional dan kurang aktif, key activities terbatas pada produksi, revenue streamhanya mengandalkan penjualan, key resources kurangnya jumlah mesin dan tenaga kerja, key partnership 
kurangnya penyuplai bahan baku dan suku cadang, dan cost structureharga bahan baku fluktuatif dan masih memiliki kredit pada perbankan.Setelah dilakukan identifikasi kekuatan, kelemahan, peluang serta ancaman pada setiap elemen yang terdapat pada elemen bisnis model kanvas, ditemukan faktor - faktor bagi perbaikan model kanvas.Perbaikan model bisnis kanvas disusun berdasarkan analisis SWOT. Perbaikan ini memiliki penambahan pada beberapa elemen, yaitu customer segments, customer relationship, channels, key activities, revenue stream, key resources, key partnership, dan cost structure.Alternatif strategi yang dihasilkan adalah pengembangan segmen pasar,peningkatan kualitas produk, penambahan tenaga kerja dan kualitas SDM, pemanfaatan teknologi tekstil dan inovasi, bekerja sama menambah mitra potensial,dan penambahan modal usaha

\section{Saran}

Saran yang dapat diberikan berdasarkan penelitian agar perusahaan mengimplementasikan hasil penelitian ini sebagai strategi dalam mengembangkan bisnis. Beberapa yang disarankan adalah penambahan tekhnologi baru water jet loom serta inovasi dalam pemasaran dan interaksi dengan pelanggan. Penelitian mengenai penambahan segmen pasar melalui sewa (makloon) perlu dilakukan, agar perusahaan mampu melakukan estimasi keuntungan yang dapat diperoleh dan tidak memangkas kemampuan produksi CV MSA pada musim-musim tertentu yang ramai. Perusahaan harus konsistensi dalam pengawasan dan penerapan strategi jangka pendek agar mampu menopang strategi jangka panjang.

\section{DAFTAR PUSTAKA}

[API] Asosiasi Pertekstilan Indonesia. 2007. The Indonesian textile and clothing outlook: prospect and challenge on global competitiveness era. http://www.unescap.org/tid/mtg/weaving_indo. pdf. [30 Desember 2018].

[ASEAN]ASEAN ONE VISION ONE IDENTITY ONE COMMUNITY. 2018. The Economic Benefits to ASEAN of the ASEAN-China Free Trade Area (ACFTA) by Raul L. Cordenillo - ASEAN | ONE VISION ONE IDENTITY ONE COMMUNITY. https://asean.org/?static post=the-economic-benefits-to-asean-of-theasean-china-free-trade-area-acfta-by-raul-1- cordenillo [16 Agustus 2018].

Asmara A, Purnamadewi YL, Meiri A.2014.Struktur biaya industri dan pengaruhnya terhadap kinerja industri tekstil dan produksi tekstil Indonesia. Jurnal Manajemen \&Agribisnis 11(2):110-118.

Adelita, Hubeis M, Kadarisman D. 2010.Kelayakan dan strategi pengembangan usaha pembudidayaan tenun setengahjadidi komplek perumahan Bekasi (kasus usaha tenun setengah jadi adenium pada lahan terbatas).Manajemen IKM 5(1):32-41.

Agostini A. 2014. Differences in business model innovation, a challenges perspective [disertasi]. Halmstad: Halmstad University College.

Baso T, Astuti Y. 2013. Competitiveness development strategy in textile industri center of Cigondewah Bandung, Indonesia. International Journal of Science and Research (IJSR) 4(11):203-208.

Balassa B. 1965. Trade liberalization and "Revealed" comparative advantage. The Manchester Schoold 33(2):99-123.https://doi.org/10.1111/j.14679957.1965.tb00050.x.

Berman SJ. 2012. Digital transformation: opportunities to create new business model. Strategy and Leadership. 40(2): 16-24.https://doi. org/10.1108/10878571211209314.

Eppler MJ, Hoffman F, Bresciani S. 2011. New business models through collaborative idea generation. International Journal of Innovation Management 15(6): 1323-1341. https://doi. org/10.1142/S1363919611003751.

Dawson RM, Moseley JF.1974., Some observations of weft insertion by water jet. Journal of Textile Institute 65(10): 639-644. https://doi. org/10.1080/00405007408630046.

Hengky. 2000. Strategi Pemasaran Ekspor Produk Perusahaan Tekstil PT. TTR Bogor [tesis]. Bogor: Sekolah Pascasarjana, Institut Pertanian Bogor.

Hidayat AM. 2002. Formulasi strategi PT. Unitex.Tbk [tesis].Bogor: Sekolah

[Kemenperin] Kementerian Perindustrian.2017.Jabar Validasi Data Industri Tekstil. http://www. kemenperin.go.id/artikel/14038/Jabar-ValidasiData-Industri-Tekstil.\%20Dipetik\%2011\%20 28\%2018:15 [16 Agustus 2018].

Kuncoro M. 2011. Krisis global dan industri. Kompas, September 2011.

Kuncoro M.2013. Indonesia's textile and its products industry: Recent development and challenges. International Journal of Businesess and Economic Development 4(2):60-74. 
Kosasi VM. 2015. Analisis dan evaluasi model bisnis pada pantai seafood restaurantdengan pendekatan business model canvas. AGORA 3(1):314-323.

Lingga JR. 2001. Formulasi strategi PT.Sierad Feedmill [tesis]. Bogor: Sekolah Pascasarjana, Institut Pertanian Bogor.

Liem F. 2009. Inovasi dan strategi pencapaiannya. Jurnal Teknik Industri 11(2): 95-100.

Maryani Y. 2000. Kajian pengendalian mutu proses produksi garmen di PT. Citra Abadi Sejati [tesis]. Bogor: Sekolah Pascasarjana, Institut Pertanian Bogor.

Marahakim S, Wandebori H. 2012. Business model generation of Majalah EPIK.Journal of Business and Management 1(5): 365-369.

Nikolao IE, Evangelinos KI. 2010. A SWOT analysis of environmental management practices in greek mining and mineral industry. Resources Policy 35(3): 226-234. https://doi.org/10.1016/j. resourpol.2010.02.002.

Nurmanisa A, WIlopo, SanawiriB. 2016.Analisis customer segment,Channels dan customer relationship dalam pembentukan value proposition Starbucks Coffee. (Studi Kasus pada Starbucks Coffee Indonesia).Jurnal Administrasi Bisnis 34(1):10-18.

Purwadi T. 2012. Pengaruh faktor internal dan eksternal terhadap profitabilitas perusahaan tekstil yang terdaftar di Bursa Efek Indonesia tahun 20052011 [tesis]. Bogor: Sekolah Pascasarjana, Institut Pertanian Bogor.

Prambudyo O. 2002. Formulasi strategi CV Enggal pratama dalam menghadapi perubahan lingkungan yang berlokasi di Kecamatan Majalaya Kabupaten Bandung [tesis]. Bogor: Sekolah Pascasarjana, Institut Pertanian Bogor.

Susanto A.2017. Analisis daya saing dan strategi pengembangan industritekstil di Indonesia[tesis]. Bogor: Sekolah Pascasarjana, Institut Pertanian Bogor.
Sianipar EM.1998. Kajian sistem pengendalian mutu produk garment pada PT. Busana Perkasa Garments Bogor [tesis]. Bogor: Sekolah Pascasarjana, Institut Pertanian Bogor. Pascasarjana, Institut Pertanian Bogor

Shafaei R.2009. Analytical approach to assessing the competitiveness in the textiles industries. Journal of Fashion Marketing \& Management 13(1):20 36.https://doi.org/10.1108/13612020910939851.

Slavik S, Bednar R. 2014. Analysis of business model. Journal of Competitiveness 6(4):19-40. https:// doi.org/10.7441/joc.2014.04.02.

Supriyadi.2006.Perlukan mendesain bisnis model baru?.Jurnal Manajemen Prasetya Mulya XX (90).

Tahernejad H. 2012. A study n effect of brand credibility on word of mouth: with reference to internet service providers in Malaysia. International Journal of Marketing Studies 4(1): 26-37. https://doi.org/10.5539/ijms.v4n1p26.

Tambunan T. 2009. Export-oriented small and medium industri clusters in Indonesia.Emerald Insight. https://doi.org/10.1108/17506200910943661.

Tirta A. 2007. Analisis manajemen modal kerja perusahaan industri tekstil (studi kasus: PT Benang Utama) [tesis]. Bogor: Sekolah Pascasarjana, Institut Pertanian Bogor.

Tim PPM Manajemen. 2012. Busines Model Canvas: Penerapan di Indonesia. Jakarta: Penerbit PPM.

Umar H. 2002. Strategic Management in Action. (Cetakan ke 2). Jakarta: PT Gramedia Pustaka Utama

Yan JY.2014. Competitive analysis of fumian clothing industry based on diamond model. Applied Mechanics and Materials 687-691:4930-4933. https://doi.org/10.4028/www.scientific.net/ AMM.687-691.4930. 